\title{
Articulate Storyline Media To Improve French Ability Students Unimed French Education Study
}

\author{
$1^{\text {st }}$ Rabiah Adawi ${ }^{1}, 2^{\text {nd }}$ Evi Eviyanti ${ }^{2}$ \\ \{rabiahfbs@yahoo.co.id ${ }^{1}$, eviko65@gmail.com² ${ }^{2}$. \\ UNIMED, 08126455579¹, UNIMED, 085371393591²
}

\begin{abstract}
Media articulate storyline to improve the writing skills of students of the French Language Education Study Program, State University of Medan. The research target to be achieved is an increase in student learning outcomes of the French Language Education Study Program at the State University of Medan by using the media articulate storyline. The media articulate storyline has important features including quizzes, conversations, discussions and input of learning materials in various formats. The resulting products can be in the form of web and applications that can be operated offline. The research method in this study uses research and development (Research and Development) Borg and Gall consists of ten implementation steps.
\end{abstract}

Keywords: Articulate storyline media, french ability, students unimed french education study .

\section{Introduction}

In learning a language, learning the structure is one of the most important things. Difficulties in learning the language due to the structural differences between Indonesian and French. This is in line with the opinion of Samsuri [1] "the striking structural differences with Indonesian cause difficulties in learning the language". That's why the writer is interested in conducting research in the field of this structure due to the mistakes made by students in using it in French sentences. Success in the teaching and learning process is learning media, one of which is Articulate Storyline media and textbooks. The component of the teaching delivery strategy for achieving certain learning outcomes is the learning media. Learning media is one of the teaching aids for lecturers because learning media can help students understand the content of the presentation. The use of adjectives in comparatives is still wrong by students, such as the following examples.

a. Monique et Marie sont plus jolies que Martine.

\section{Written:}

(Monique and Marie are prettier than Martine).

In the sentence above, the adjective joli(e) is written jolies because the subject is plural feminine. Meanwhile, for masculine subjects, the plural adjective only ends in "s" without the letter "e" like the adjective poly(e) in the sentence below. 
b. Martine et son frère sont aussi polis que leurs amis.

\section{Written:}

(Martine and her brother are just as polite as their friends).

The above-mentioned rules regarding changes in adjectives according to the type and number of subjects apply to adjectives that change regularly. Changes in adjectives as above are one of the regular changes in adjectives and in general, changes in adjectives that change regularly are like the changes described above. Although most adjectives in French are regular adjectives, there are also adjectives that change irregularly.

The use of adverbs that express the wrong quantity in the comparative is as follows:

a. Hélène va au cinéma deux fois par semaine.

(Helena goes to the movies twice a week)

b. Pilou va au cinéma huit fois par mois.

(Pilou goes to the movies eight times a month).

From the statement above, sentences using comparatives can be formed as follows:

a. Hélène va au cinéma aussi souvent que Pilou.

(Helene goes to the movies as often as Pilou).

b. Pilou va au cinéma aussi souvent qu' Hélène.

(Pilou goes to the movies as often as Helene).

However, students write a comparative of the above statement as follows:

Hélène va au cinéma *plus souvent que Pilou.

(Helene goes to the movies more often than Pilou).

From the example of the error in sentence la above, it can be clearly seen that students have not been able to know the use of adverbs aussi and plus. If students understand the use of additional, students will use it as in sentences 1 and 2. And if students understand the use of adverb plus then they will not use it in sentence 1a because the comparative does not match the existing statement.

So students must understand that for comparatives expressing the same level, the adverb aussi is used instead of plus or moins. And vice versa, for the comparative level, the adverb plus is used instead of aussi or moins.

Then the use of adjectives in comparative which is still wrong is done by students as in the following examples.

c. Monique et Marie sont plus jolies que Martine.

(Monique and Marie are prettier than Martine).

Written :

d. Monique et Marie sont plus jolis que Martine.

In sentence 3 the adjective joli(e) is written jolies because the subject is plural feminine. As for masculine subjects, the plural adjective only ends in "s" without the letter "e" like the adjective poly(e) in sentence 5 below.

e. Martine et son frère sont aussi polis que leurs amis.

(Martine and her brother are just as polite as their friends).

The above-mentioned rules regarding changes in adjectives according to the type and number of subjects apply to adjectives that change regularly. Changes in adjectives as above are one of the regular changes in adjectives and in general, changes in adjectives that change regularly are like the changes described above. Although most adjectives in French are regular adjectives, there are also adjectives that change irregularly. 
The examples of errors above show that students do not understand the use of adjectives in French, especially qualifying adjectives. Since the use of adjectives is an integral part of this comparative, we must also pay close attention to the use of these adjectives.

In addition to mistakes made by students in writing adjectives in comparative, students are also not skilled in using adjectives and other adverbs which are exceptions to the usual forms of comparison level as described in the previous section.

The adjectives and adverbs are the meilleur(e) and meilleur(e)s adjectives and the mieux adverb. Adjective meilleur(e) is used for comparative plus bon (feminine: plus bonne) which means better. While the comparative adverb mieux of plus bien (better). So the comparative plus bon (feminine: plus bonne) and plus bien are not applied because they are not in accordance with the rules of French structure.

Example :

1. Marinette est meilleure élève que sa soeur.

(Marinette is a better student than her sister).

In sentence 1 the adjective meilleure comes from the adverb plus and the adjective bonne because the subject is singular feminine and if the subject is plural feminine then the adjective becomes meilleures.

2. Elles sont meilleures que sa soeur.

(They are "girls" better than her sister).

\section{Method}

Descriptive method has properties and characteristics that are considered very suitable to be used for this study. Description of grammatical and semantic categories of language evaluation is done through testing the form, meaning and relationship with the elements of the text or discourse obtained specifically from the French language text at UNIMED.

The research method in this study uses research and development (Research and Development) Borg and Gall [2] consists of ten implementation steps.

\section{Result and Discussion} offline.

The resulting products can be in the form of web and applications that can be operated 


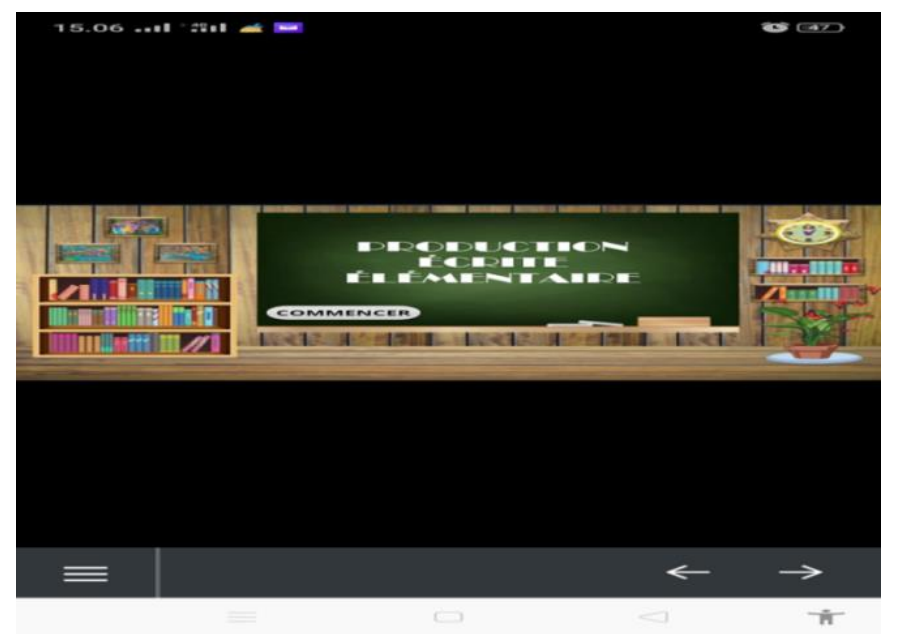

Fig. 1. Home

\subsection{Adverb}

The use of comparative level forms is closely related to adverbs, especially adverbs that express quantity (adverbe de quantité) and adverbs that explain how (adverbe de manière), so students must also understand adverbs morphologically and syntactically. The following will explain what exactly these adverbs are.

In the linguistic dictionary, Harimukti Kridalaksana [3] states, adverbs are words used to describe verbs, adjectives or other adverbs, for example: very, more, not and so on. Dubois [4] stated, the adverb is an invariable word that modifies. The meaning of an adjunct, verb, or other adverb. Adverbs are unchanging words that can clarify the meaning of an adjective, verb or other adverb.

Then Albert Hamon [5] also added about the location of adverbs as follows: l'adverbe est un mot invariable qui placé au près d'un autre mot, modifie le sens de ce mot. Ce mot peut être un verbe, un adjectif ou un autre adverbe. Adverb is a word that is placed next to another word and makes the meaning of that word clearer. Words that can be clarified by adverbs are in the form of adjectives or other adverbs.

Regarding the adverb form mentioned by Lagane [6] as follows. Adverbs can be.

a. Word

Example : bien [bje] 'baik'(good), toujours [tu:zur] 'selalu'(always)

fort [fo:r] 'kuat'(strong), là [la] ' disana'(there)

b. Locust Adverbia

Example : tout de suite [tud:syt] à l'envi [a lã vi] 'persaingan'

\subsection{Adjectives}

In French, an adjective called an adjective means a class of words added to a noun that can be placed before or after a noun. Based on its function, adjectives are divided into two, namely qualificative adjectives and non qualificative adjectives. 
Qualificative adjectives serve to explain the nature of a noun, while non-qualificative adjectives serve to give instructions relating to the addition of a determinator to a noun. Etymologically, adjectives are also divided into three parts, namely pronominal adjectives, numeral adjectives and qualifying adjectives.

3.2.1 Adjectif Pronominal. It is called a pronominal adjective because it relates to the form and meaning of the pronoun and relates to the addition of a determinant to the noun.

Which includes pronominal adjectives are:

- adjectif possessif, Example : mon chat (my cat)

- adjectif demonstratif, Example : ce chat (that cat)

- adjectif indefini, Example : tout chat (all cats)

- adjectif interrogatif, Example : quel chat (which cat)

- adjectif relatif, Example : lequel chat (this cat).

3.2.2 Adjectif Numeral. Adjectif numéral replace the article or pronominal adjective, it is located in front of the noun and is divided into:

- adjectif numéral cardinal

Example : un, deux, trois, etc (one, two, three, etc).

- adjectif numéral ordinal

Example : prémier, deuxième, troisième, etc ((first, second, third, etc).

3.2.3 Adjectif qualificative. Among the companions of the noun, the qualificative adjective is the most important because it completes and enriches the meaning of the noun. When compared with articles and pronominal adjectives that determine nouns, the presence of qualificative adjectives is less mandatory. However, qualificative adjectives can complement and enrich the meaning of nouns.

Example : - un chat 'a cat'

- un beau chat 'a beautiful cat'

In general, the feminine 'qualificative adjective' is formed by adding -e to the masculine adjective.

Example : noir $\rightarrow$ noire 'black'

pur $\rightarrow$ pure 'pure'

\section{Conclusion}

Media articulate storyline to improve the writing skills of students of the French Language Education Study Program, State University of Medan.

\section{References}

[1] Samsuri. Analisis Bahasa. Jakarta : Erlanggal; 2016.

[2] Gall, Meredith D.Gall Joyce P. \& Borg, Walter R. Educational Research An Introduction, Seventh Edition. Boston: Pearson Education Inc; 2011.

[3] Kridalaksana, Harimukti. Kamus Linguistik. Jakarta : Gramedia; 2012.

[4] Dubois J, Rene L. La Nouvelle Grammaire du Française. Paris : Librairie Larouse; 2011 
[5] Hamon, Albert. Grammaire Pratique. Paris : Hachette; 2011

[6] Rene L. Grammaire Française. Paris : Librairie Larouse; 2012 